\title{
New data about Cenomanian and Turonian chert from the Charente basin (France)
}

\author{
Mar Rey-Solé ${ }^{1}$, Xavier Mangado ${ }^{1}$ and Christophe Delage ${ }^{2}$ \\ 1. Seminari d'Estudis i Recerques Prehistòriques, Dept. Prehistòria, Història Antiga i Arqueologia, Universitat de \\ Barcelona, C/Montalegre, 6, 08001, Barcelona, Spain. \\ Email : Rey-Solé: mreysole@ub.edu; Mangado: mangado@ub.edu \\ 2. Département de Prehistoire, Muséum National d'Histoire Naturelle, Paris, France. \\ Email: delage.chris@laposte.net
}

\begin{abstract}
:
Prehistoric studies in lithic raw materials have experienced some methodological innovations that have resulted in research breakthroughs. The transfer of methods from Geology to Archaeology has led to the development of a new discipline, Petroarcheology, which has allowed to go beyond the study of chert as a raw material, providing archaeological responses from Petrography's own methods.

Why did we choose the Charente's basin samples?

The history of research goes back to early 2000, with works like the PCR led by Anne Delagnes "Paléolithique Moyen dans le bassin de la Charente" and the doctoral thesis of Seon-Jing Park (2007), in relation to the question of Neanderthal human mobility and potential mineral resources of that basin. These works led to the initiation of different geoarchaeological surveys in search of quality siliceous raw materials for the manufacture of stone tools, whose positive results led, in 2002, to the creation of the regional lithothèque of Charente (Angoulême, France).

This lithothèque, located at the Museum of Fine Arts in Angoulême and with a collection of 183 samples of siliceous rocks - chert, jasper (Riba, 1997) and claystones (Riba, 1997)-, has become over the years an essential and very important tool for scholars interested in siliceous raw material availability and procurement in that region.

Our study has combined petrologic and micropalaeontological (both macroscopic and microscopic) analysis of all samples recovered from two of the four geological stages of the Upper Cretaceous represented in the lithothèque - Cenomanian and Turonian.

We've described some different kind of chert and we've made location maps with the aim, in the future, of compare and relate to archaeological studies on the origin of lithic industries recovered in the archaeological deposits of the area.
\end{abstract}

Keywords: petroarcheology; lithotheque; chert; petrological collections; Charente; raw materials

\section{Resumen:}

Los estudios en Prehistoria sobre materias primas han experimentado ciertas innovaciones metodológicas que se han traducido en grandes avances en la investigación. La conjunción de métodos

Published by the School of History, Classics and Archaeology, University of Edinburgh ISSN: 2055-0472. URL: http://journals.ed.ac.uk/lithicstudies/

This work is licensed under a Creative Commons Attribution 2.5 UK: Scotland License. 
procedentes de la Geología hacia la Arqueología, ha supuesto el desarrollo de una nueva disciplina, la Petroarqueología, que ha permitido ir más allá en el estudio del sílex como materia prima, proporcionando respuestas de carácter arqueológico a partir de los métodos propios a la petrografía.

¿Por qué la elección de muestras de la Charente?

Los antecedentes de la investigación se remontan a inicios del año 2000, a raíz de los trabajos de Anne Delagnes, "El Paleolítico medio en la cuenca de la Charente" y la tesis doctoral de Seon-Jing Park (2007), en relación a la cuestión de la movilidad humana neandertal y los recursos minerales potenciales de dicha cuenca. Estos trabajos provocaron el inicio de diferentes prospecciones geoarqueológicas, en búsqueda de materias primas silíceas de calidad para la confección de utillaje lítico, cuyos resultados positivos dieron lugar, en el año 2002, a la creación de la Litoteca Regional de la Charente (Angulema, Francia).

Esta litoteca, ubicada en el Museo de Bellas Artes de Angulema y con un fondo compuesto por 183 muestras de rocas silíceas (sílex, jaspes y arcillitas), se ha convertido con los años en una herramienta fundamental para los estudiosos de las materias primas silíceas de la región.

Nuestro estudio ha conjugado análisis petrológicos y micropaleontológicos (tanto macroscópicos como microscópicos) de la totalidad de las muestras procedentes de dos de los cuatro pisos geológicos del Cretácico superior representados en la litoteca - Cenomaniense y Turoniense- .

Se han descrito diferentes tipos de sílex y se han elaborado sendos mapas de localización con el propósito, en un futuro, de poderlos comparar y relacionar con estudios arqueológicos sobre la procedencia de la industria lítica recuperada en los yacimientos de la zona y así comprender el porqué de ciertos comportamientos humanos.

Palabras clave: petroarqueología; litoteca; sílex; colección pétrea; Charente; materias primas

\section{Introduction}

For several years starting in 2002, Anne Delagnes led a research project entitled "The Middle Palaeolithic in the Charente basin", in which one of the main topics was about human mobility in relation to potential mineral resources. Meanwhile, Seong-Jin Park conducted a doctoral thesis on lithic production systems and the movement of raw materials in that region (Park 2007). In the course of this project were conducted several surveys to complete prior existing information (Séronie Vivien \& Lenoir, 1987; Séronie-Vivien 1972; Séronie-Vivien and Séronie-Vivien, 1987).

Simultaneously, but independently, Christophe Delage carried out prospections for chert ${ }^{1}$ outcrops in that same region, but more specifically within a $15 \mathrm{~km}$ radius of the prehistoric (Magdalenian) site of La Chaire-à-Calvin. This work provided a lot of information in relation to the amount and variety of chert outcrops in the area. A total of 123 chert-bearing outcrops from the Cretaceous were visited and sampled (Delage 2005; Delage et al. 2006), provide strong evidence about the availability of mineral resources in the immediate vicinity of the site.

These surveys were combined with important laboratory work, based on a macroscopic characterization of the samples. It was in this context that the Regional Lithothèque of the Charente's basin (France) was created (Féblot-Augustins et al., 2010). Located in the Fine Arts Museum of Angoulême this reference collection is composed of 183 samples of siliceous rocks -chert, jasper (Riba, 1997) and claystones (Riba, 1997). ${ }^{2}$ The research potential of this Lithothèque lies in the fact that it provides data (such as the geological and geographical context of the samples) for the future identification of cherts recovered in various archaeological contexts.

Lithic materials are important at two different levels: the archaeological and the geological levels. As a geological matter, the natural entities of these rocks must be studied with natural sciences methodologies. But, on the other hand, since they have been modified 
by humans, they are an archaeological remain, and thus they must be approached through cultural and technological analysis as well (Mangado, 2004). Masson (1981) stated in her thesis that cherts are siliceous rocks "with memory". Thus, by studying their mineralogical, textural and structural components we can place them in a well-defined geographical space and at a specific geological time (see also Mangado, 2004: 11).

However, only an approach from the perspective of Social Sciences and Humanities may allow an interpretation of the human groups who used them as an economical or symbolical resource. Thus, to achieve its goals, Prehistoric Archaeology (as the most naturalistic of the human sciences) needs to draw on more empirical methodologies, such as Petroarcheology, to study the lithic assemblages from the two perspectives mentioned before (Mangado, 2002). The interest of petrographic analysis applied to archaeology relies on the creation of an empirical corpus of data to infer palaeoeconomic information resulting from human activity (Mangado, 2002). Such data set must be based on a specific protocol, which follows successive steps of observations and comparisons at different scales (Figure 1).

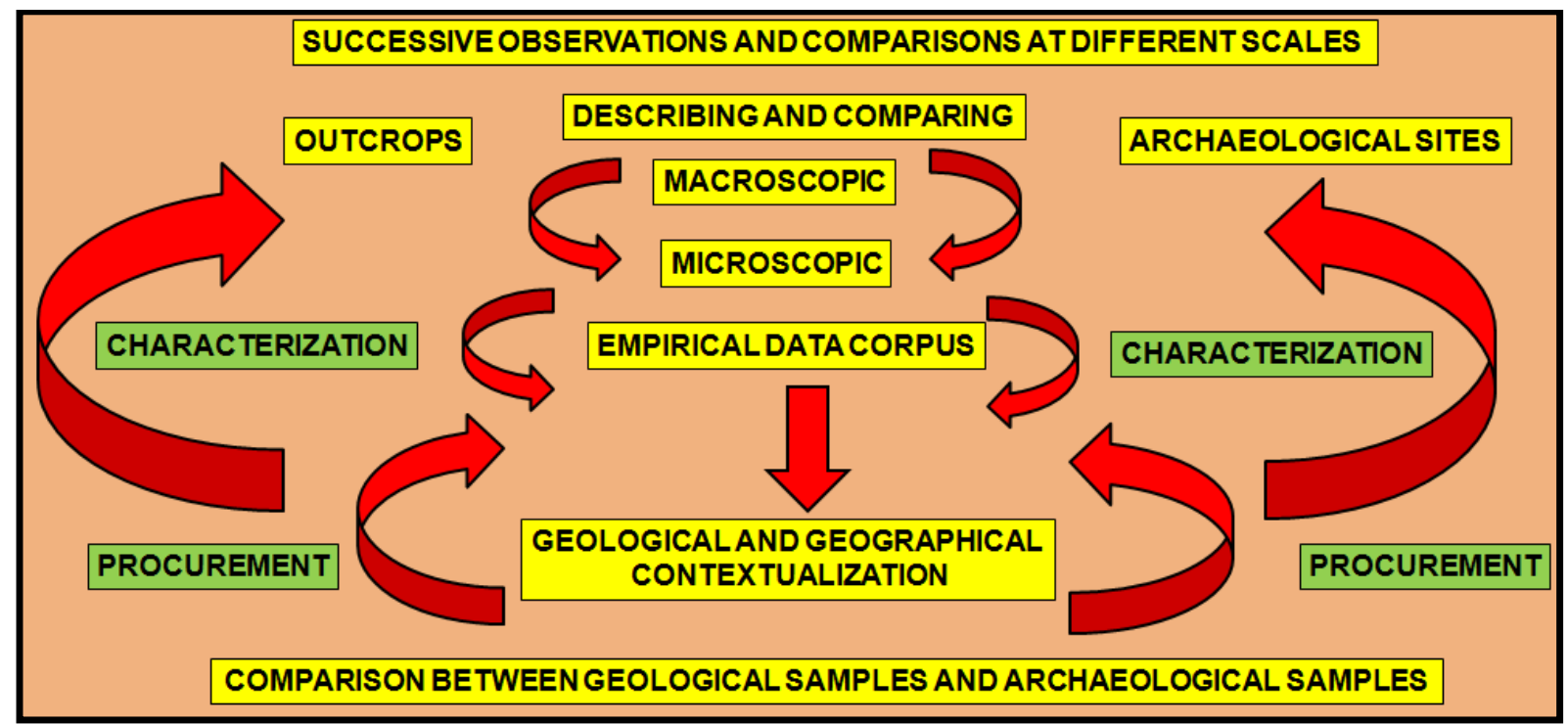

Figure 1. Petroarcheological methodology (Mangado \& Rey-Solé, 2013).

\section{Material and methods}

The Chaire-à-Calvin rockshelter is a prehistoric site located in Mouthiers (France) (Figure 2) that has been prolific (there have been more than a single occupation, from Middle to Upper Magdalenian), notably in terms of the recovery of chipped stones (de SonnevilleBordes, 1987). Their analysis may provide answers to several questions regarding the origin of these stone tools.

The study of the raw materials of this site has not been conducted yet. Thus there is a lack of knowledge about the mobility of the prehistoric communities inhabiting the area. There is no doubt that the only raw material used for the production of the lithic assemblage was chert, although different varieties of chert can be easily identified to the naked eye. Thus it seems evident that the different varieties have different geological and geographical origin, without further analysis.

The first step in this research on the Charente basin Lithothèque corresponds to the implementation of a petrological study, intended to categorize different types of cherts. As a side effort, it will locate geographically the different outcrops on the map.

Second, the same petrological methodology could be applied to the study of the archaeological lithic industry, through a comparison with the geological dataset. With the 
observation, description and identification of the lithic assemblage recovered at the site we will produce a petroarcheological corpus data, to be compared with the corpus of data of the geological samples of the lithothèque from Charente's basin, which has been previously studied. From this research we intend to approach the origin of the raw materials used to produce the lithic tools, by locating the source of the cherts recovered at the site.

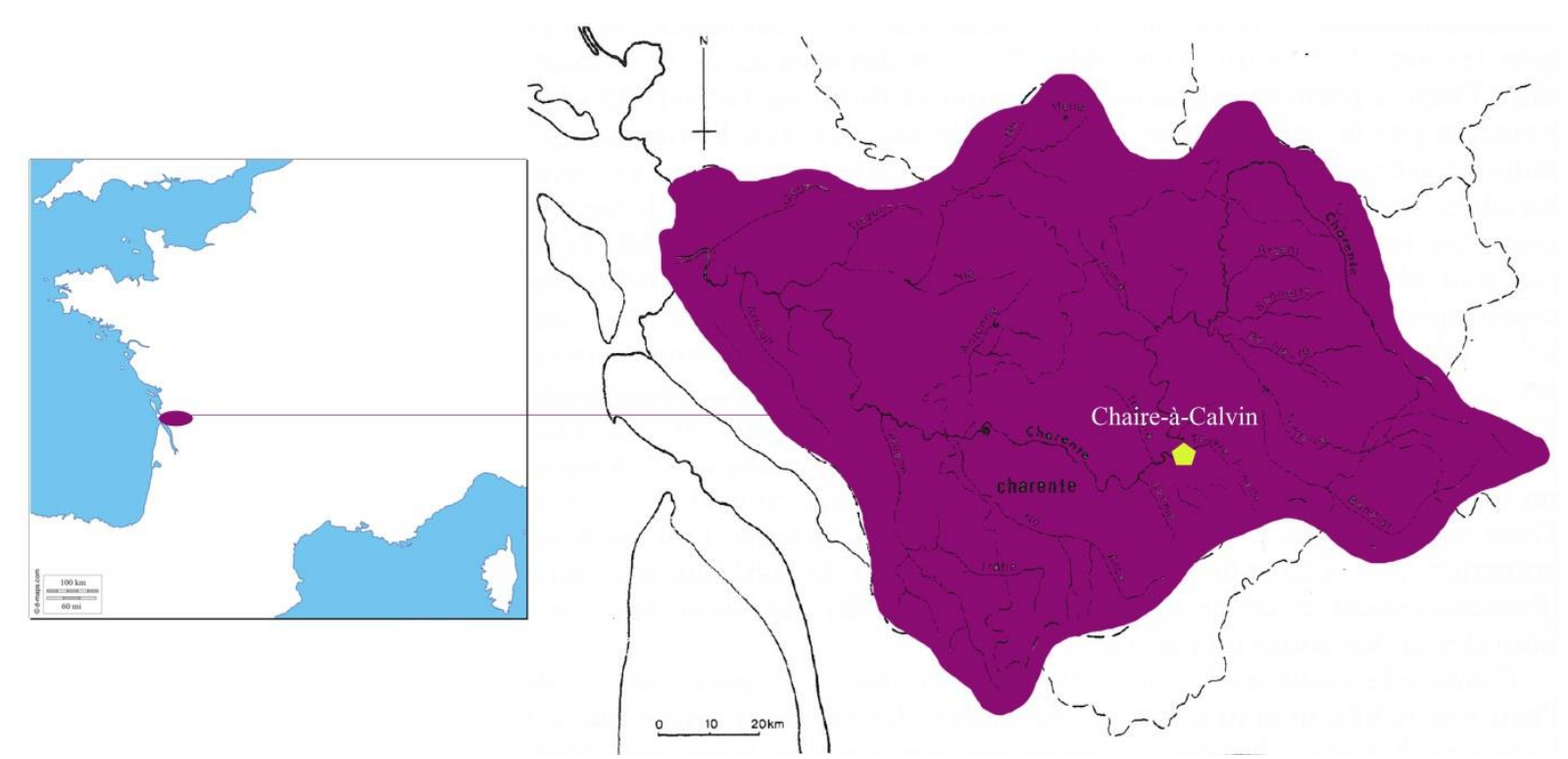

Figure 2. Charente's basin and the Chaire-à-Calvin site (modified from d-maps.com).

This is how the archaeopetrological study of the siliceous raw materials recovered at Chaire-à-Calvin site will allow us to understand and reconstruct the degree of mobility of the Upper Palaeolithic populations occupying the site and leaving behind traces of their activities.

The study of two geological ages, the Cenomanian and the Turonian, was the first step of our research related to the Charente basin Lithothèque. We studied 59 geological samples of chert, 55 of them came from 22 Turonian outcrops (16 in its original position and 7 in secondary location ${ }^{3}$ ) and 4 samples came from 4 primary Cenomanian outcrops.

The methodological approach consists in the textural analysis -both macroscopic (including naked eye and binocular magnifier) and microscopic- of all samples.

The macroscopic analysis was conducted by naked eye and also using a binocular magnifier (Olympus stereomicroscope with KL 1500 LCD cold light source) between $0.67 \mathrm{x}$ to $4.5 \mathrm{x}$ magnification ranges. The macroscopic description takes into account parameters as: colour, degree of patina, homogeneity, brightness, petrographic siliceous elements, texture, structure and micropaleontological contents (Dunham 1962; Luedtke 1992; Pettijohn 1970; Rey 2011; Riba 1997) (Figure 3). Many different types of carbonate relics (Foraminifera, bryozoans, algae, spicules, echinoderm plates, thecal plates of crinoids, etc.) revealed the silicification process and were significant of the original sedimentary environment. Depends on the carbonate relict it was identified at macroscopic level and/or at microscopic level.

28 thin sections of these previous samples were prepared at the Thin Section Laboratories of the University of Barcelona to analyse it by the Petrographic Microscope. The mineralogy, texture and structure of these samples have been analysed (Vallès Garcia et al., 2006.). The microscopic description focuses on 3 criteria (Rey-Solé, 2011): siliceous components as: megaquarzt, microquarzt, chalcedony and opal; non-siliceous components as: host rock, micropaleontology, skeletal and non-skeletal components, pseudomorphs, relict textures and other relict or authigenic minerals (Figure 4); and finally diagenetic aspects, such as dolomitisation and anhydritation identified by cross-polarized light microscopy. 
The study of the fossil record has been also useful to discriminate varieties, origins and provenances. These two levels of analysis have allowed us to differentiate several types of chert showing different characteristics.

Finally mention that SEM was used but did not give the expected results.

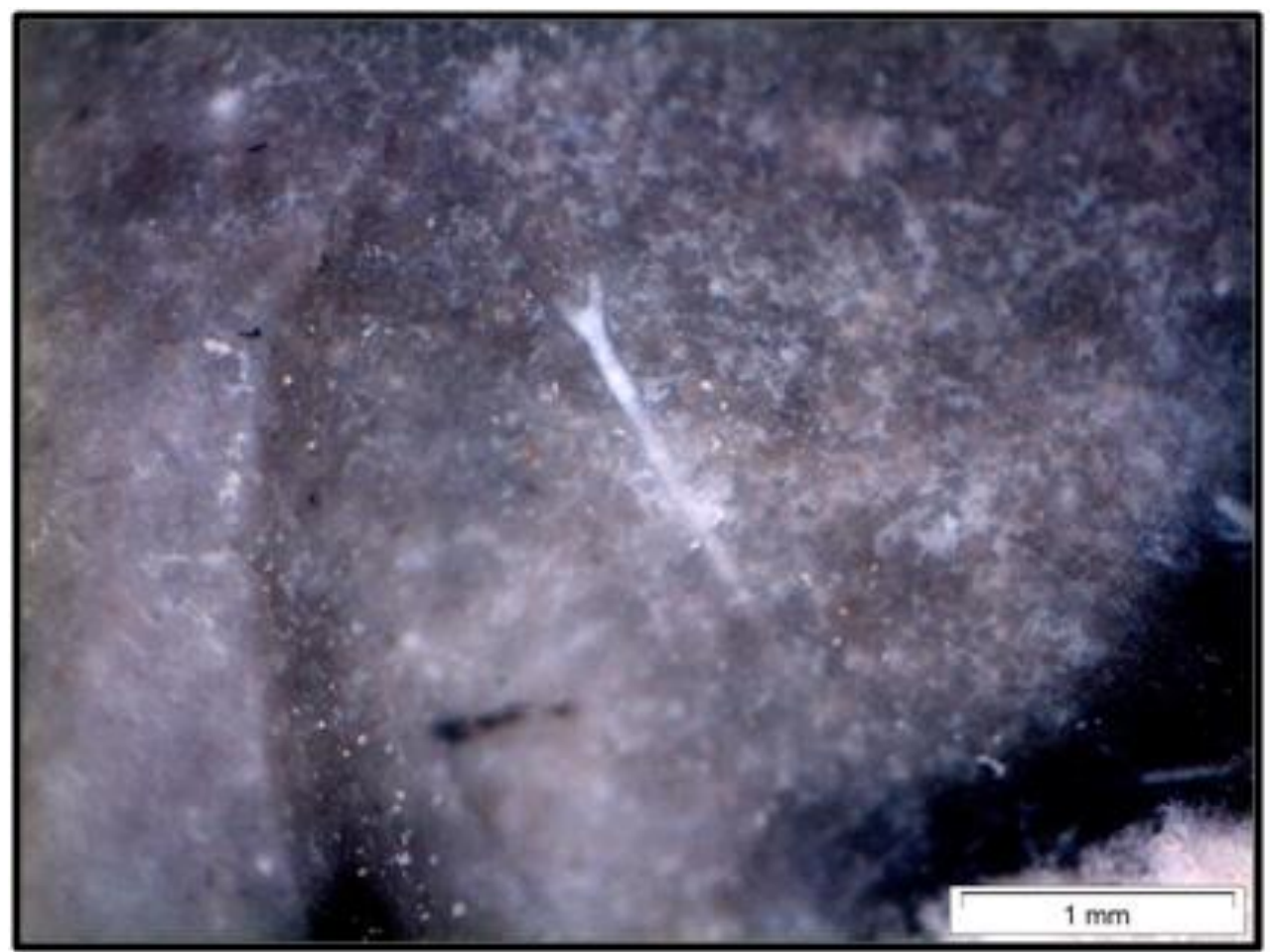

Figure 3. Carbonate relict of spicule from sample number 41-4. Cimenteries Lafarge. Macroscopic level. Binocular magnifier (3x).

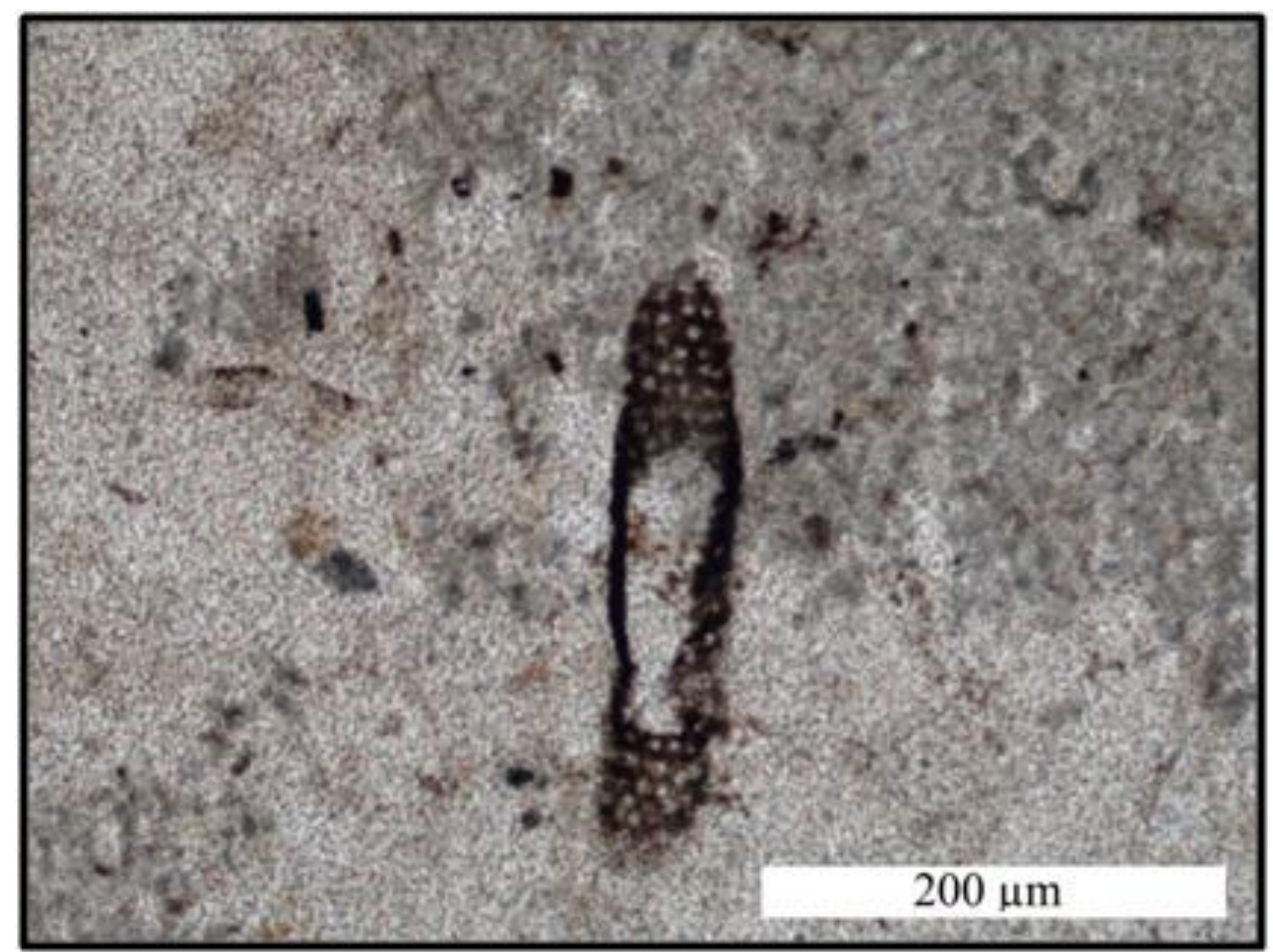

Figure 4. Radiolarian sample num. 41-4. Cimenteries Lafarge. Microscopic level. Petrographic microscope (20x). 


\section{Results}

The methods of analysis used in this research have provided many information, especially the petrographic analysis with a wide-ranging empirical dataset that allow us to define certain varieties and sub-varieties of cherts.

We have defined a total number of 11 varieties of cherts (3 Cenomanian types and 8 Turonian types) all of them coming from the Charente basin (Cenomanian Fm and Turonian Fm) (Table 1 and Table 2).

We can observe that the Cenomanian age samples are quite homogeneous, at textural and micropalaeontological level, but in any case, each variety is perfectly distinguishable. By contrast, the Turonian age samples present a great variability and multiplicity of petrographic and micropalaeontological features that characterize the different varieties of chert (Figure 5).

In summary, all varieties of chert discriminated are marine, with a high percentage of bioclasts such as foraminifera, bryozoans, echinoderms or spicules. The difference between them lies in the grain size, the texture and the structure, there are mudstone, wackestone, packstone and grainstone varieties, or with differences between its majoritary siliceous elements (Microquartz vs. Macroquartz or Chalcedony), etc.
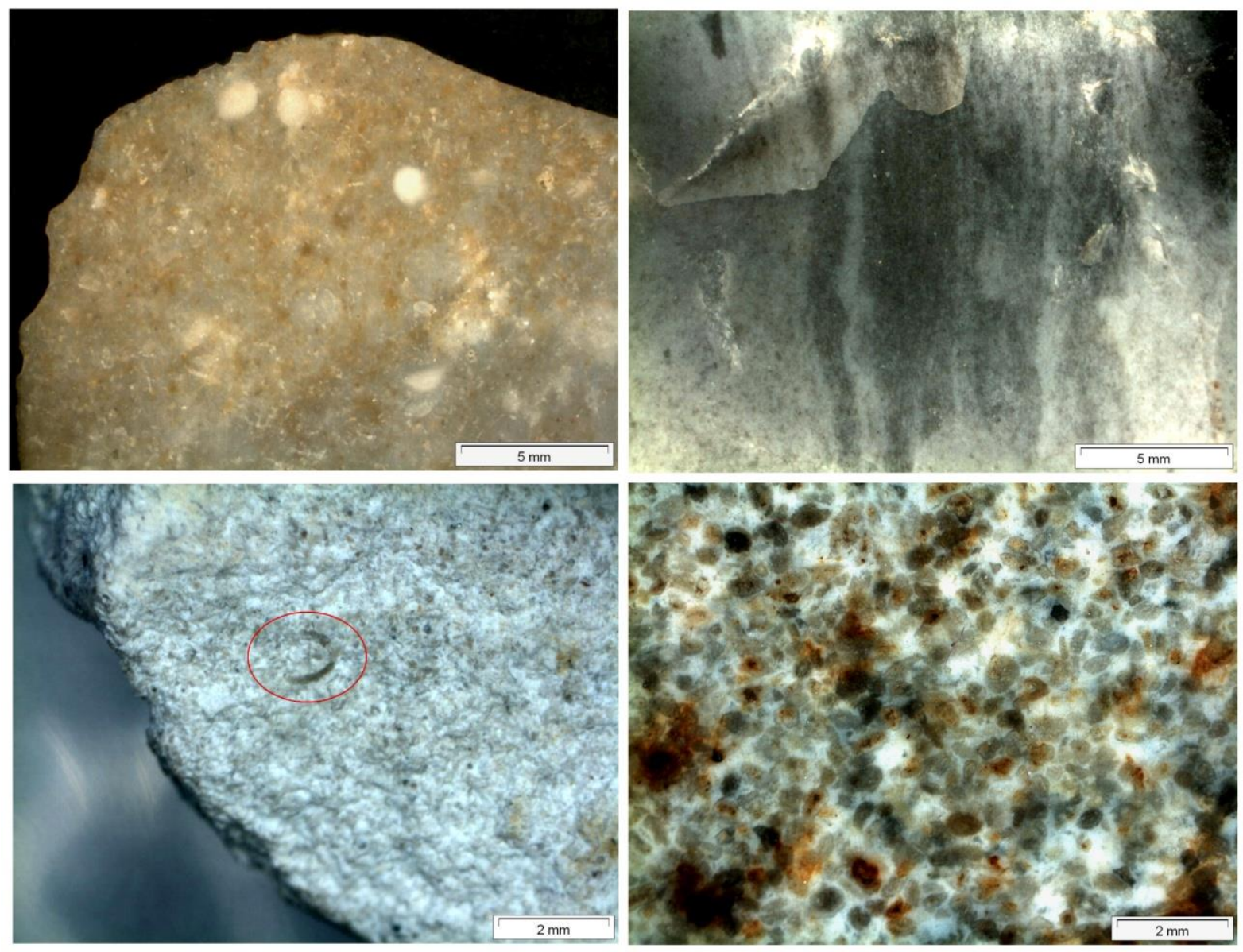

Figure5. Different textures and varieties of chert from Charente's basin. From left to right and up to down: sample 44-1 from lower Cenomanian (F1 variety), sample 63 from middle Cenomanian (F3 variety), sample 45 from middle Turonian (E2 variety) and sample 20-6 from upper Turonian (E6d sub-variety). 
Table 1. Macroscopic characteristics of defined types. (Rey-Solé 2013).

\begin{tabular}{|c|c|c|c|c|c|c|c|}
\hline \multicolumn{8}{|c|}{ MACROSCOPIC ANALYSIS } \\
\hline & Variety & Subvariety & Samples & Texture & Grain size & Colour & Observations \\
\hline \multirow{3}{*}{ Cenomanien } & F1 & & $\begin{array}{l}44-1,44-2 \\
44-3,51\end{array}$ & Packstone & Coarse & HUE 7.5YR $4 / 2$ & $\begin{array}{l}\text { Orbitolinidae, Brachiopoda, } \\
\text { glauconite, peloids }\end{array}$ \\
\hline & $\mathrm{F} 2$ & & 100 & Mudstone & $\begin{array}{l}\text { Fine to } \\
\text { Medium }\end{array}$ & HUE 2.5Y 5 & Azoic, stromatolitic structure \\
\hline & F3 & & $\begin{array}{l}61,62,63 \\
65\end{array}$ & Mudstone & Very fine & HUE 2.5 Y $5 / 2$ & $\begin{array}{l}\text { Azoic, concentric zonation, metalic } \\
\text { oxids, microgeodes }\end{array}$ \\
\hline \multirow{12}{*}{ Turonien } & \multirow{2}{*}{ E1 } & E1a & 2, craix 2 & Mudstone & Very fine & HUE 2.5 Y $5 / 3$ & $\begin{array}{l}\text { Micropaleontology in the cortex, } \\
\text { rombhoidal pseudomorphs }\end{array}$ \\
\hline & & E1b & $1,8-7,8-8$ & Mudstone & Very fine & $\begin{array}{l}\text { HUE } 2.5 \text { Y } 6 / 1 \text { y } \\
\text { HUE } 10 \text { YR } 5 / 2\end{array}$ & $\begin{array}{l}\text { unkown micropaleontology, } \\
\text { bioturbation traces }\end{array}$ \\
\hline & E2 & & 45 & Packstone & Medium & HUE $2.5 \mathrm{Y} 6 / 1$ & $\begin{array}{l}\text { Dasycladae, Bryozoa, benthonic } \\
\text { Foraminifera, frag. of shell }\end{array}$ \\
\hline & E3 & & $\begin{array}{l}16-1,16-2, \\
20-1,20-3, \\
20-4,41-3, \\
41-4,48-1, \\
76-1,77-1\end{array}$ & Mudstone & Very fine & HUE 2.5Y 2.5/1 & $\begin{array}{l}\text { Spicules, frag. of shell, relictual } \\
\text { Foraminifera, metallic oxids }\end{array}$ \\
\hline & E4 & & $\begin{array}{l}66-1,66-2 \\
66-3,73-1 \\
77-2\end{array}$ & Mudstone & Very fine & HUE $2.5 Y 5 / 2$ & $\begin{array}{l}\text { Isolated spicules, Incertae sedis, } \\
\text { metallic oxids, preferred orientation } \\
\text { of the elements }\end{array}$ \\
\hline & E5 & & $\begin{array}{l}47-2,48-2 \\
76-3,76-6 \\
81\end{array}$ & Mudstone & Very fine & HUE10YR 4/2 & $\begin{array}{l}\text { Bryozoa, benthonic Foraminifera, } \\
\text { frag. of Echinoderma, shells and } \\
\text { Brachiopoda }\end{array}$ \\
\hline & \multirow{4}{*}{ E6 } & E6a & $\begin{array}{l}40-2,40-5 \\
67-1,76-4\end{array}$ & Mudstone & $\begin{array}{l}\text { Fine to } \\
\text { Medium }\end{array}$ & HUE 2.5 Y 5/1 & $\begin{array}{l}\text { Abundantes foraminiferos e Incertae } \\
\text { sedis }\end{array}$ \\
\hline & & E6b & $72-2,82-1$ & Wackestone & $\begin{array}{l}\text { Fine to } \\
\text { Medium }\end{array}$ & HUE 10YR 5/2 & $\begin{array}{l}\text { Spicules (including relicts), Bryozoa, } \\
\text { fragm. of shell andIncertae sedis }\end{array}$ \\
\hline & & E6c & $\left|\begin{array}{l}20-2,40-1, \\
40-4,41-2, \\
49,74-1,76- \\
5,72-1,96-1\end{array}\right|$ & Packstone & Medium & HUE 10YR 4/4 & $\begin{array}{l}\text { Fragm. Echinoderma, Bryozoa, } \\
\text { Miliolidae, benthonic Foraminifera, } \\
\text { shells, plant remains, Incertae Sedis }\end{array}$ \\
\hline & & E6d & $20-6$ & Grainstone & $\begin{array}{l}\text { Medium to } \\
\text { Coarse }\end{array}$ & HUE 7.5YR $3 / 2$ & $\begin{array}{l}\text { Miliolidae, biseriat Foraminifera, } \\
\text { Bryozoa and frag. of Shell }\end{array}$ \\
\hline & E7 & & $\begin{array}{l}20-5,40-3 \\
76-2,47-1 \\
171-1\end{array}$ & $\begin{array}{l}\text { Wackestone- } \\
\text { Packstone }\end{array}$ & $\begin{array}{l}\text { Fine to } \\
\text { Medium }\end{array}$ & HUE $2.5 \mathrm{Y} 6 / 2$ & $\begin{array}{l}\text { Bryozoa, spicules, Miliolidae, } \\
\text { Incertae sedis, textural zonation }\end{array}$ \\
\hline & E8 & & $41-1,79$ & Mudstone & $\begin{array}{l}\text { Fine to } \\
\text { Medium }\end{array}$ & HUE 10YR 4/6 & $\begin{array}{l}\text { Poor preferred micropaleontology, } \\
\text { recristalisations, mottled structure }\end{array}$ \\
\hline
\end{tabular}


Table 2. Microscopic characteristics of defined types. (Rey-Solé 2013).

\begin{tabular}{|c|c|c|c|c|c|c|c|}
\hline & \multicolumn{7}{|c|}{ MICROSCOPIC ANALYSIS } \\
\hline & Variety & Subvariety & Samples & Texture & Siliceos components & Micropaleontology & Observations \\
\hline \multirow{3}{*}{ Cenomanien } & F1 & & $44-3,44-1$ & $\begin{array}{l}\text { Packstone- } \\
\text { Grainstone }\end{array}$ & $\begin{array}{l}\text { Microquartz (70\%), } \\
\text { Chalcedony }(40 \%)\end{array}$ & $\begin{array}{l}>70 \% \text { : varios foraminifera } \\
\text { including miliolids, shell, } \\
\text { echinoderm and } \\
\text { gasteropoda fragm. }\end{array}$ & $\begin{array}{l}\text { Banded - } \\
\text { Chalcedony/Microquartz, } \\
\text { differential conservation of } \\
\text { the micropaleontology, } \\
\text { pelloids }\end{array}$ \\
\hline & $\mathrm{F} 2$ & & 100 & Packstone & $\begin{array}{l}\text { Chalcedony (57\%) } \\
\text { Microquartz (40\%) }\end{array}$ & $\begin{array}{l}>60 \%: \text { unknown } \\
\text { micropaleontology }\end{array}$ & $\begin{array}{l}\text { Poorly preserved } \\
\text { micropaleontology and } \\
\text { reemplaced by Chalcedony }\end{array}$ \\
\hline & F3 & & 63 & Wackestone & Microquartz (75\%) & $\begin{array}{l}<25 \% \text { : spheric Radiolaria, } \\
\text { unknown fragments }\end{array}$ & $\begin{array}{l}\text { Relict micropaleontology } \\
\text { and metallic oxides, } \\
\text { stratified microfacies (=E1) }\end{array}$ \\
\hline \multirow{12}{*}{ Turonien } & & E1a & 2 , craix 2 & $\begin{array}{l}\text { Wackestone- } \\
\text { Packstone }\end{array}$ & Microquartz (80\%) & $\begin{array}{l}>60 \% \text { : Echinoderma frag. } \\
\text { Benthonic Foraminifera, } \\
\text { Bryozoa, Tintinidae } \\
\text { ressembling }\end{array}$ & $\begin{array}{l}\text { Stratified microfacies, } \\
\text { rombhoidal pseudomorphs } \\
\text { relicts }\end{array}$ \\
\hline & & E1b & $1,8-7$ & Mudstone & Microquartz (99\%) & $\begin{array}{l}20 \% \text { : Echinoderma frag. } \\
\text { And unknwon Foraminifera }\end{array}$ & $\begin{array}{l}\text { Stratified microfacies } \\
\text { (Radiolaria/Microquartz) }\end{array}$ \\
\hline & E2 & & 45 & Grainstone & $\begin{array}{l}\text { Microquartz (77\%), } \\
\text { Megaquartz (20\%) }\end{array}$ & $\begin{array}{l}>90 \% \text { : unknwon relictual } \\
\text { Foraminifera, Ostracoda, } \\
\text { Echinoderma picks }\end{array}$ & $\begin{array}{l}\text { Stratified microfacies } \\
\text { (Radiolaria/Microquartz) }\end{array}$ \\
\hline & E3 & & $\begin{array}{l}16-2,41-4, \\
76-1\end{array}$ & $\begin{array}{l}\text { Mudstone a } \\
\text { Wackestone }\end{array}$ & $\begin{array}{l}\text { Microquartz (56- } \\
97 \%)\end{array}$ & $\begin{array}{l}<10 \% \text { : Ostracoda, spiculs, } \\
\text { Radiolaria. }\end{array}$ & $\begin{array}{l}\text { Microcristalline microfacies } \\
(41-4,76-1) \text { and stratified } \\
(=\mathrm{E} 1)(16-2)\end{array}$ \\
\hline & E4 & & $66-3$ & $\begin{array}{l}\text { Wackestone- } \\
\text { packstone }\end{array}$ & Microquartz (65\%) & $\begin{array}{l}35 \% \text { : Incertae sedis, } \\
\text { bioturbation }\end{array}$ & $\begin{array}{l}\text { Slightly stratified } \\
\text { microfacies, very poorly } \\
\text { preserved }\end{array}$ \\
\hline & E5 & & $76-3$ & Mudstone & Microquartz (95\%) & $\begin{array}{l}<15 \% \text { : spicules, unknwon } \\
\text { frag. }\end{array}$ & $\begin{array}{l}\text { Microcristalline } \\
\text { microfacies, very poorly } \\
\text { preserved }\end{array}$ \\
\hline & \multirow{4}{*}{ E6 } & E6a & $40-5,67-1$ & Packstone & $\begin{array}{l}\text { Microquartz (63- } \\
75 \%), \text { Megaquartz } \\
(10-20 \%)\end{array}$ & $\begin{array}{l}>50 \% \text { : Miliolida and fragm } \\
\text { of Foraminifera, } \\
\text { Echinoderma, Ostracoda } \\
\text { and shells }\end{array}$ & Bioclastic Packstone \\
\hline & & E6b & no samples & & & & \\
\hline & & E6c & $\begin{array}{l}49,20-2,40- \\
4,74-1,96-1\end{array}$ & $\begin{array}{l}\text { Wackestone - } \\
\text { Packstone }\end{array}$ & $\begin{array}{l}\text { Microquartz }(99,9- \\
85 \%), \text { Megaquartz } \\
(10-5 \%)\end{array}$ & $\begin{array}{l}35 \text { al } 90 \% \text { : Miliolida, fragm. } \\
\text { of Echinoderma, shells and } \\
\text { Bryozoa }\end{array}$ & $\begin{array}{l}\text { Original carbonate } \\
\text { stuctures, metalic oxides, } \\
\text { rombhoidal pseudomorphs }\end{array}$ \\
\hline & & E6d & $20-6$ & $\begin{array}{l}\text { Packstone - } \\
\text { Grainstone }\end{array}$ & Microquartz (85\%) & $\begin{array}{l}>80 \% \text { : Miliolida, fragm. Of } \\
\text { Foraminifera, } \\
\text { Eqchinoderma, shells and } \\
\text { Ostracoda }\end{array}$ & $\begin{array}{l}\text { Bioclastic Packstone with } \\
\text { original carbonate } \\
\text { structures }\end{array}$ \\
\hline & E7 & & $\begin{array}{l}20-5,40-3 \\
76-2,47-1 \\
171-1\end{array}$ & $\begin{array}{l}\text { Wackestone- } \\
\text { Packstone }\end{array}$ & $\begin{array}{l}\text { Microquartz (90-65\% } \\
\text { Chalcedonite (35- } \\
5 \%)\end{array}$ & $\begin{array}{l}50 \% \text { : fragm. Echino., } \\
\text { shells, Foraminifera, } \\
\text { Bryozoa, spicules, } \\
\text { Ostracoda }\end{array}$ & $\begin{array}{l}\text { Bioclasts in replacement } \\
\text { process, rombhoidal } \\
\text { pseudomorphs and relicts }\end{array}$ \\
\hline & E8 & & $41-1$ & Wackestone & $\begin{array}{l}\text { Microquartz (90\%) } \\
\text { Megaquartz (5\%) }\end{array}$ & $\begin{array}{l}30 \%: \text { fragm of Rudist, } \\
\text { Radiolaria (= E3) }\end{array}$ & Microcristalline microfacies \\
\hline
\end{tabular}


In the future, these defined varieties, will serve as a reference for the comparative petroarchaeological study of the stone-tools from the archaeological site of Chaire-à-Calvin (Figure 6).

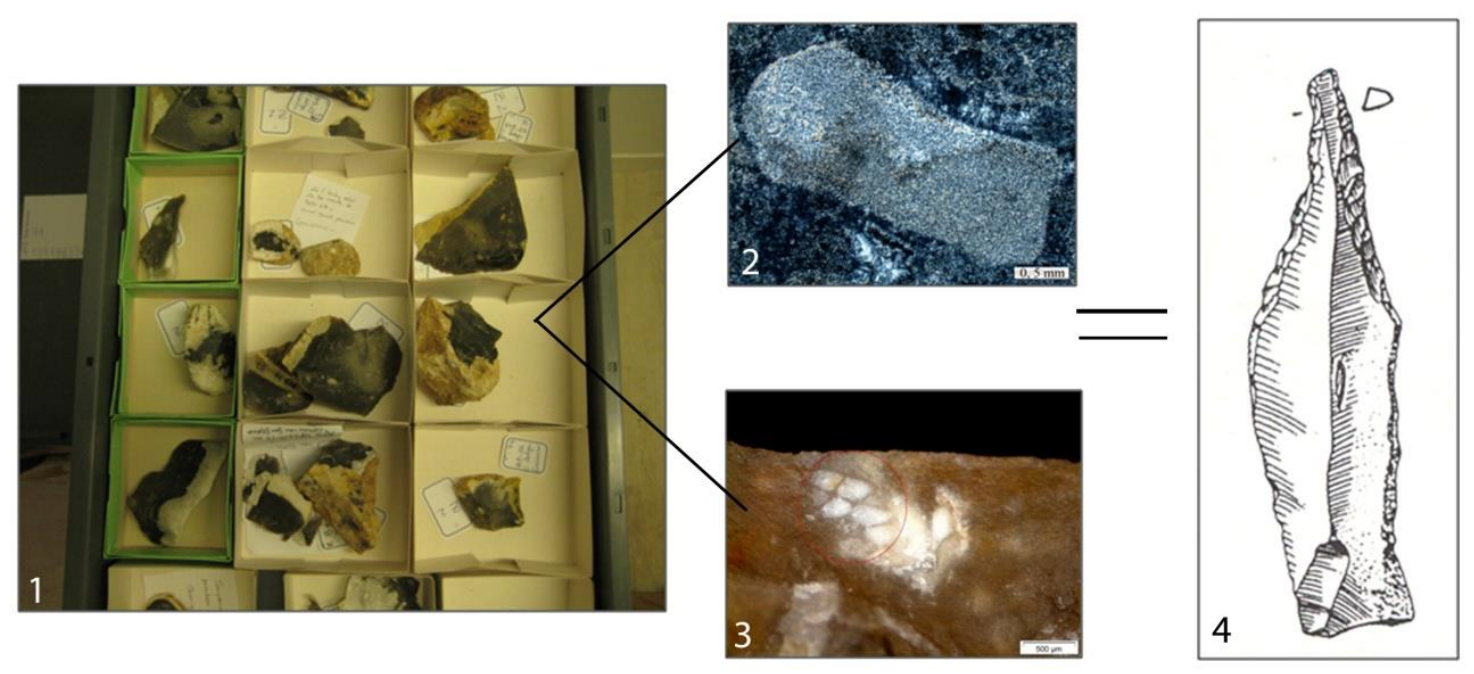

Figure 6. Simplified scheme for the next archaeopetrological study of comparison of geological and archaeological samples of Chaire-à-Calvin. 1. The lithothèque. 2. Microscopic photography of an echinoderm plate. 3. Macroscopic photography of thecal plates of a crinoid, both from La Couronne outcrop (Upper Turonian). 4. Perçoir from Chaire-à-Calvin.

The next step in our research and one of the objectives of this characterization of samples from the lithothèque has been to create maps of the Cenomanian and Turonian outcrops of the Charente's basin, in order to represent cartographically the siliceous resources and their characteristics in the territory. These maps are related to each one of the chert varieties with their particular characteristics (Figure 7).

At this point, we can consider that the Cenomanian and the Turonian cherts are quite well defined, at least, for the samples collected in a radius of around $15 \mathrm{~km}$ from the archaeological site of Chaire-à-Calvin. The resulting database will be useful to compare geological and archaeological samples in order to deduce the original environmental conditions of these cherts and thereby help in the future research in archaeopetrology of lithics of the site.

The next step to undertake would be try to answer some relevant questions, such as: which degree of mobility was developed by these populations looking for these raw materials? How many types of cherts were used in the manufacturing process of the stone tools? Why?

\section{Conclusions}

This study presents the preliminary results of our petroarchaeological research of the lithic collection of Chaire-à-Calvin site. The first step, which is the one presented in this paper, has been focused on the analysis of the existing geological lithothèque, while the analysis of the archaeological assemblage will be conducted in the near future. The research has shown the presence of different varieties of chert, with different characteristics pointing to different sources. 
This paper shows once more how the characterization of the lithic raw materials through purely geological disciplines (such as Petrography and Micropalaeontology), provides significant information to understand the processes of mobility of prehistoric communities. Thus helping archaeologists to understand certain human behaviours, such as the collection and sourcing of lithic raw materials.

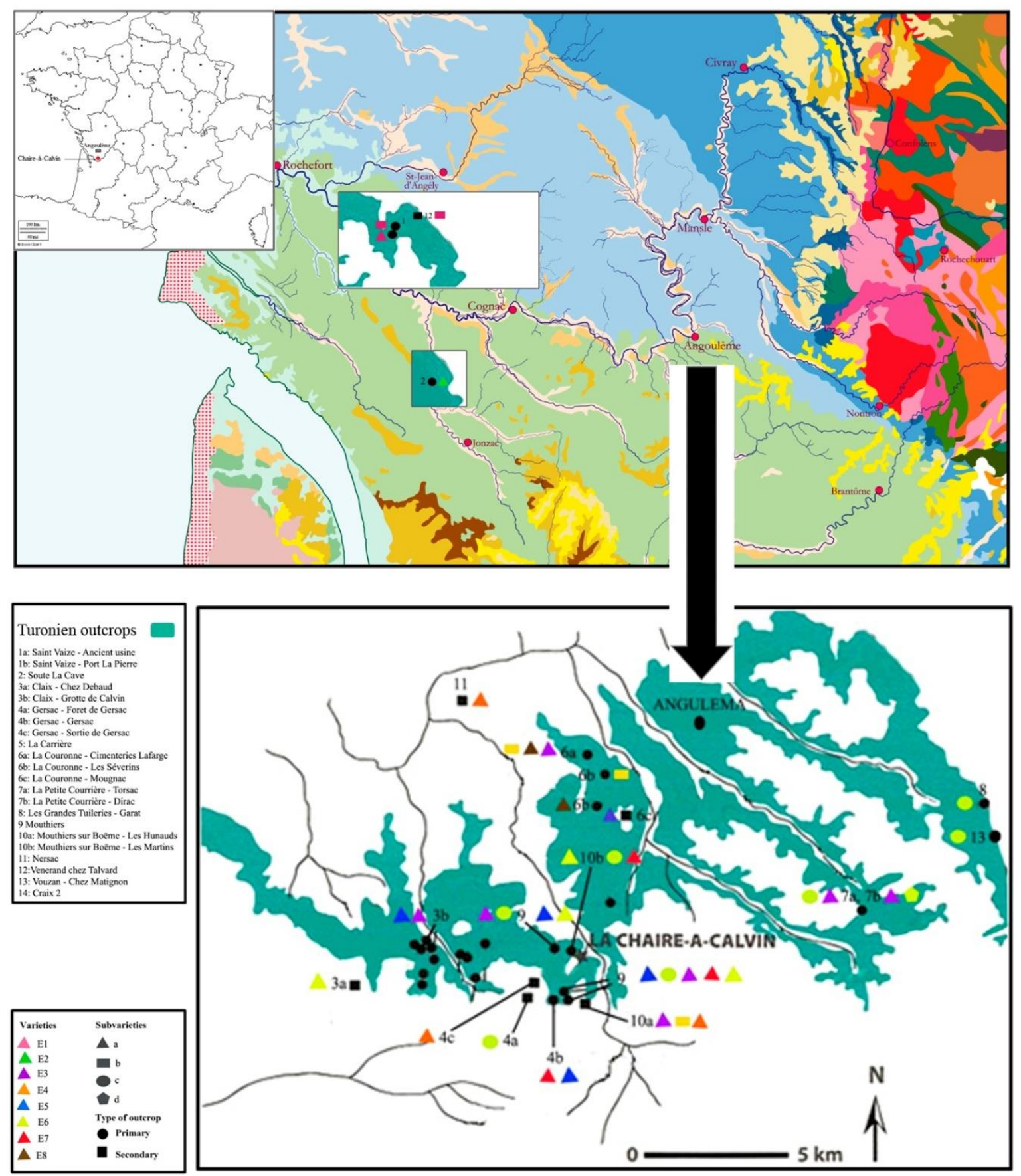

Figure7. Location map of the Turonian varieties of chert from Charente's basin. Modified from Delage (2006) and Féblot Augustins \& Monthel (2010). 


\section{Notes}

1. The term 'chert' refers to microcrystalline quartz found in calcareous parent rocks. It also includes materials found in chalk, which are sub-categorised as 'flint'.

2. There are data sheets that include photos, available on the Internet to ensure better dissemination of information: http://www.alienor.org/ARTICLES/lithothèque/index.htm

3. 'Secondary location' and 'position' refers to materials transported from bedrock outcrop by any dynamic process (i.e., Materials transported by riverbeds or materials included in conglomerate rock).

\section{Acknowledgements}

This paper have been possible thanks to: Musée d'Angoulême, HAR2011 26193 project (Ministerio de Economía y Competitividad) and "Els recursos lítics de les societats caçadores-recol-lectores - PGIR 08/09" Project. We would like to thank Jean-François Tournepiche for his constant support.

\section{References}

Delage, C. 2005. Inventaire de la lithothèque 2005, Musée d'Angoulême, France: 48 p., (unpublished), (in French) ("Lithothèque inventory").

Delage, C., Santallier, D., Platel, N. 2006. Project de recherche : La Chaire-à-Calvin (Mouthiers-sur-Boëme, Charente), rapport d'activités, Service Régional de l'Archéologie du Poitou-Charentes, France: 96 p., (unpublished). (in French) ("Research project: Chaire-à-Calvin (Mouthiers-sur-Boëme, Charente) activity report")

Dunham, R.J. 1962, Classification of Carbonate Rocks According to Depositional Texture. In: HAMM, W.E (Ed.), Classification of Carbonate Rocks: A Symposium, American Association of Petroleum Geologists, p. 108 - 121.

Féblot-Augustins, J., Park, S. J., 2010, Circulation des matières premières et modalités d'exploitation territoriale au Paléolithique moyen récent dans le bassin de la Charente. In: CONARD, N.J. and DELAGNES, A. (Eds.), Settlement Dynamics of the Middle Paleolithic and Middle Stone Age. Kerns-Verlag, Tübingen: p. 397- 426. (in French) ("Raw material circulation and territory exploitation modalities in the Charente Basin during the Middle Palaeolithic")

Féblot-Augustins, J., Park, S.J., Delagnes, A., 2010, Etat des lieux de la lithothèque du bassin de la Charente, Service Régional de l'Archéologie du Poitou-Charentes, France: 72 p., (unpublished). (in French) ("Report of the Charente's basin Lithothèque")

Luedtke, B. E., 1992, An archaeologist's guide to chert and flint, Archaeological Research Tools, 7: 165 p., Institute of Archaeology, University of California, Los Angeles.

Mangado, J., 2002, La caracterización y el aprovisionamiento de los recursos líticos en la Prehistoria de Cataluña. Las materias primas silíceas del Paleolítico Superior final y Epipaleolítico, Ph.D. Dissertation, University of Barcelona, 425 p. (in Spanish) ("Caracterization and captation of lithic ressources during Prehistory in Catalonia")

Mangado, X., 2004, L'arqueopetrologia del sílex. Una clau per al coneixement paleoeconòmic $i$ social de les poblacions prehistòriques, Societat Catalana d'Arqueologia, Barcelona, 116 p. (in Catalan) ("The archaeopetrology of chert. A key to understanding the social and paleoeconomical knowledge of prehistoric groups"). 
Masson, A., 1981, Pétroarchaeologie des roches siliceuses. Intérêt en Préhistoire, Unpublished Ph.D. Dissertation, University Claude Bernard-Lyon I, Lyon: 101 p. (in French) ("Petroarchaeology of siliceous rocks. Interest in Prehistory")

Park, S.-J., 2007, Systèmes de production lithique et circulation des matières premières au Paléolithique moyen récent et final. Une approche techno-économique à partir de l'étude des industries lithiques de La Quina (Charente), Unpublished Ph.D.

Dissertation, Universiy of Paris X-Nanterre, Paris, 210 p. (in French) (Systems of lithic production and circulation of raw materials in recent and final Middle Palaeolithic)

Pettijohn, F. J., 1970, Rocas sedimentarias, 2nd ed., Eudeba, Buenos Aires: 731 p. (in Spanish) (“Sedimentary rocks")

Rey-Solé, M., 2011, Aproximación al estudio arqueopetrológico de la litoteca de la cuenca de la Charente (Francia), Master's Thesis, University of Barcelona, Barcelona, 161 p. (in Spanish) ("Archaeopetrological study of the Charente Basin's Lithothèque")

Riba, O., 1997, Diccionari de Geologia, Enciclopèdia Catalana, Institut d'Estudis Catalans, Barcelona: 1407 p. (in Catalan) ("Dictionary of Geology")

Séronie-Vivien, M.-R., Lenoir, M., 1987, Le silex de sa genèse à l'outil, Actes du Vo colloque international sur le silex (Vth international Flint symposium), Bordeaux, 17 sept- 2 octobre 1987, Cahiers du Quaternaire Vol. 17, Centre National de la Recherche Scientifique, Paris, p. 200-235. (in French) ("Chert from its genesis to a lithic tool”)

Séronie-Vivien, M., Séronie-Vivien, M.R., 1987, Les silex du Mesozoïque nord-aquitain. Approche géologique de l'étude des silex pour servir a la recherche préhistorique. Bulletin de la Société Linnéenne de Bordeaux (Supplement du Tomme XV), 645 p. (in French) ("The North Aquitaine Mesozoic chert. Geological approach to the study of chert to serve a prehistoric research")

Séronie-Vivien, M., 1972, Contribution à l'étude du Sénonien en Aquitaine septentrionale, ses stratotypes: Coniacien, Santonien, Campanien In: Les stratotypes Français, v. II, Comité français de stratigraphie, Centre National de la Recherche Scientifique, Paris: 195 p. (in French) ("Contribution for the study of Senonian in Aquitaine septentrional, their stratotypes: Coniacian, Santonian, Campanian. The French stratotypes”)

de Sonneville-Bordes, D., 1987, Observations sur le Magdalénien de la Chaire-à-Calvin, à Mouthiers, Charente. In: Préhistoire du Poitou - Charentes. Problèmes actuels. - Actes du 111ème Congrès national des Sociétés savantes, Poitiers, 1986, Ed. du CTHS, Paris: p. 157 - 185. (in French) ("Observations about the Magdalenian of Chaire-à-Calvin, in Mouthiers, Charente") 